\title{
Rethinking places of trauma: an interview with Silvia Costa, Government Commissioner for the preservation and re- purposing of the ex-prison complex on the island of Santo Stefano
}

\section{Ripensare i luoghi del trauma: un'intervista con Silvia Costa, Commissario di Governo per il restauro e la valorizzazione del ex-carcere dell'Isola di Santo Stefano}

\section{Flaminia Bartolini}

Leverhulme Trust Fellow ISPC-CNR

Silvia Costa is a journalist and a centre-left politician, she was elected in 2009 at the European Parliament within the SD coalition and from 2020 is the Government Commissioner for the preservation and re-purposing of the ex-prison complex on the island of Santo Stefano. The Ventotene-Santo Stefano project, which has just been dedicated to former EU Parliament President David Sassoli, seeks to preserve material and memorial legacies of two sites of confinement where the very idea of European Union was conceived.

Silvia Costa è una giornalista e un personaggio politico di centro sinistra, è stata eletta nella coalizione della Sinistra Democratica nel 2009 e dal 2020 è Commissario Straordinario di Governo per il Progetto di conservazione e rifunzionalizzazione dell'ex carcere sull'isola di Santo Stefano. Il Progetto Ventotene-Santo Stefano, recentemente dedicato allo scomparso Presidente del Parlamento Europeo David Sassoli, si pone l'obiettivo di recuperare la memoria materiale e storica di due luoghi di prigionia e confino dove l'idea di Europa unita è stata concepita.

(Italian version below)

Flaminia Bartolini: Commissioner, I imagine the role entrusted to you by the Government is a challenge. Could you tell us about the project?

Silvia Costa: The recovery of the former Bourbon prison on the island of Santo StefanoVentotene, closed and abandoned for fifty years, is a cultural, ethical, and symbolic challenge launched in Italy and in Europe by the Renzi government as early as 2016. The Conte government in January 2020 and the Draghi government in 2021, on the initiative 
of the Minister of Culture, Dario Franceschini, wanted to relaunch the project by entrusting me with the role of Extraordinary Commissioner to ensure the necessary coordination between the state administrations and the project.

This is a fascinating and complex task for which I feel a lot of responsibility, not only for the heritage value that a place of "pain, expiation and redemption" (to use the words of the enlightened director Eugenio Perucatti) represents, but also for its importance in the history of prison and criminal law and human rights.

This site conveys a powerful emotional impact linked to the 'Panoptikon' architecture, a peculiar feature in European prison construction, that gives this monumental complex an uncomfortable socio-political value.

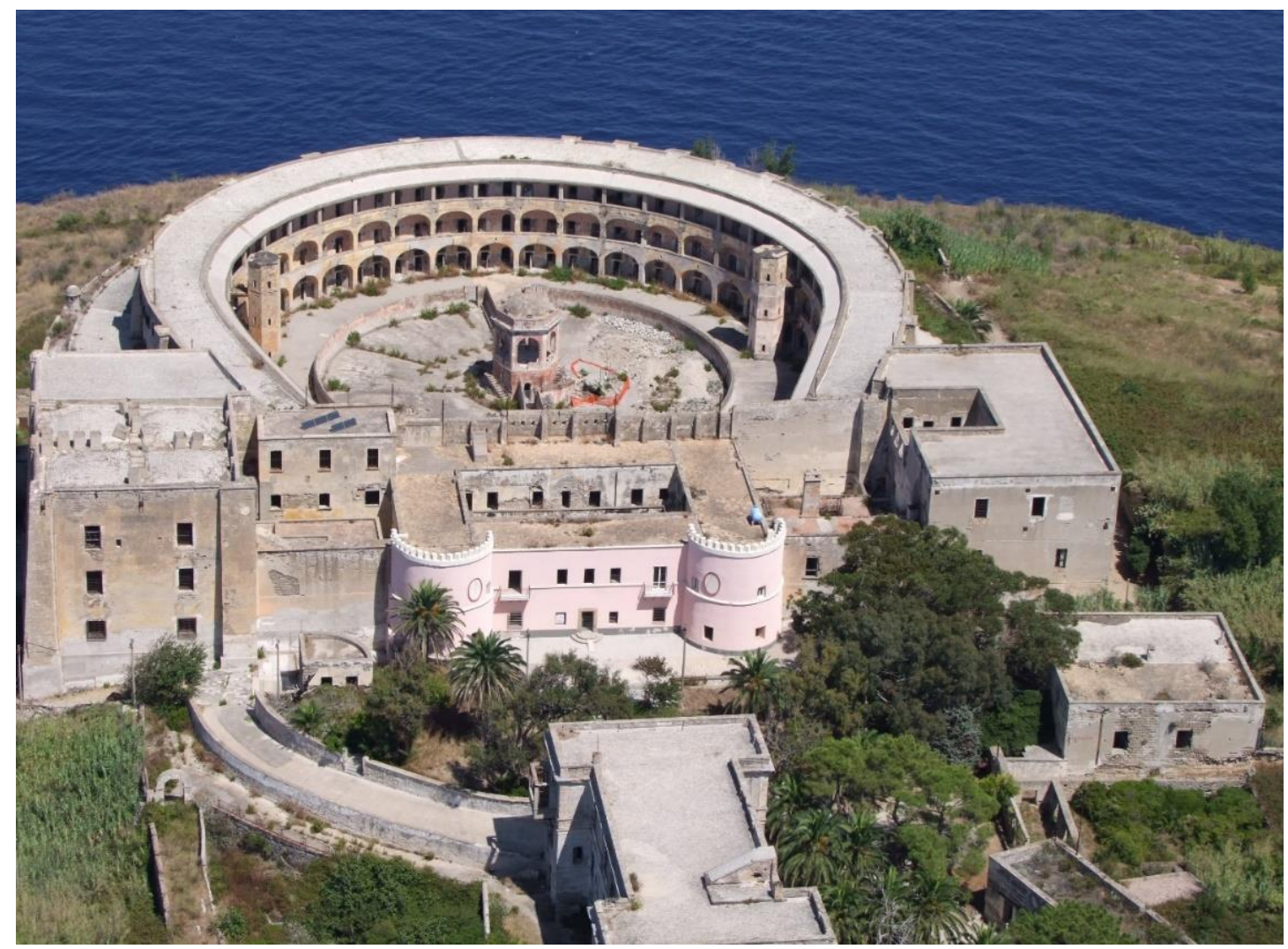

Figure 1. Island of Santo Stefano, aerial view of the prison complex (photo credits Silvia Costa).

Flaminia Bartolini: Commissioner, what is the history of the Santo Stefano prison?

Silvia Costa: The island of Santo Stefano and the nearby island of Ventotene have frequently been used in history as sites of exile. It was Julia major, daughter of Augustus, with her mother Scribonia, who first experienced exile on the island (first century BC), followed by Agrippina major by order of Tiberius, Octavia, daughter of Claudius and wife of Nero, and Flavia Domitilla, grandson of Domitian.

The project was commissioned by Ferdinand I of the Two Sicilies to install a penitentiary on the island that would serve to separate the prisoners from the rest of society. The king hired the architect Francesco Carpi, who implemented the Enlightenment principles advocated by the English philosopher Jeremy Bentham for the execution of the work. 
These principles, developed by Bentham himself in his ideal prison plan, called Panopticon, provided that all inmates locked up in their cells could be guarded by a single guardian placed in a central building. This architectural arrangement was based on the principle of dissuasion from doing evil deriving from the awareness of being constantly under control.

Even after the fall of the Kingdom of the Two Sicilies, the prison maintained its role under the Kingdom of Italy. During this period, the prison continued to accommodate common and 'special' inmates, including the best-known post-Risorgimento bandit Carmine Crocco and the anarchist Gaetano Bresci, who killed King Umberto I of Savoy.

During the Fascist period, the prison continued to be a privileged place for the internment of political dissidents. Famous inmates of this period were Umberto Terracini, Mauro Scoccimarro, Rocco Pugliese and Sandro Pertini, future President of the Italian Republic. In 1939, Pertini and Terracini were transferred to confinement on the island of Ventotene. In 1941, during that confinement, Spinelli, Rossi and Colorni conceived and wrote the Manifesto for a free and united Europe.

Things changed substantially when Eugenio Perucatti, the new director, arrived in 1952. A man of profound Christian faith and very determined, he wanted to shake up prison history through a slow transition from a very harsh life sentence to a new concept of detention: Perucatti's mission was not to repress inmates but to re-educate them so they could return to civil society.

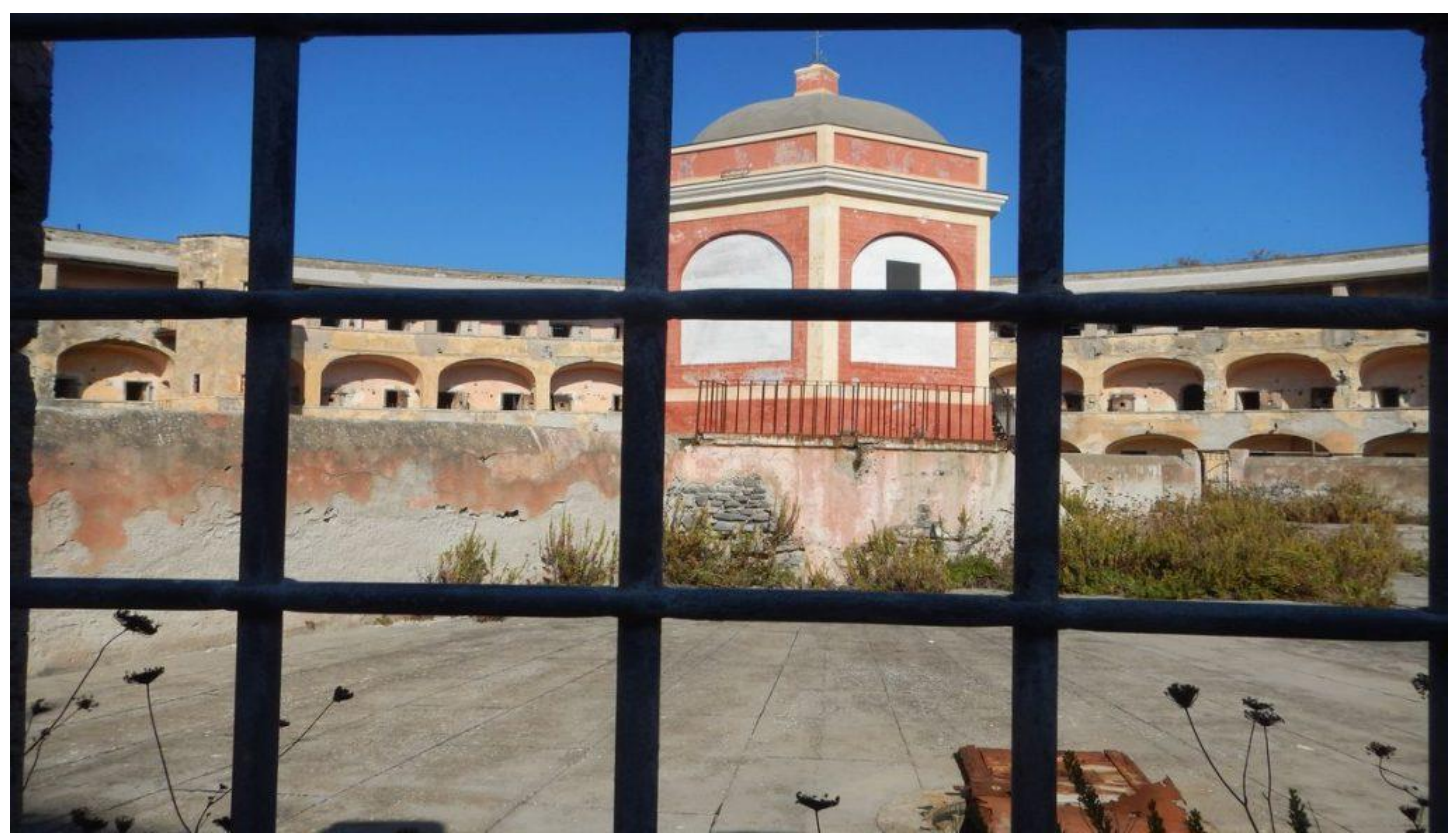

Figure 2. Island of Santo Stefano, view of the guards' room from the Panoptikon (photo credits Silvia Costa).

During his management a new penitentiary system was put in place in which spare time during the day was replaced by work, school, and religious activities. Family members could be seen once a year so that prisoner does not feel alienated from the benefits of family life/relationships.

This dream lasted only a few years, because in July 1960 Pecuratti was transferred to direct the Turi prison, in Puglia, a prison for elderly inmates. His pioneering reforms of the 
prison system anticipated art. 27 of the 1975 Italian Constitutional Charter: imprisonment cannot consist of treatments against humanity and must aim at the re-education of the condemned.

The life sentence prison on Santo Stefano was closed in February 1965, through a Decree of the Ministry of Justice.

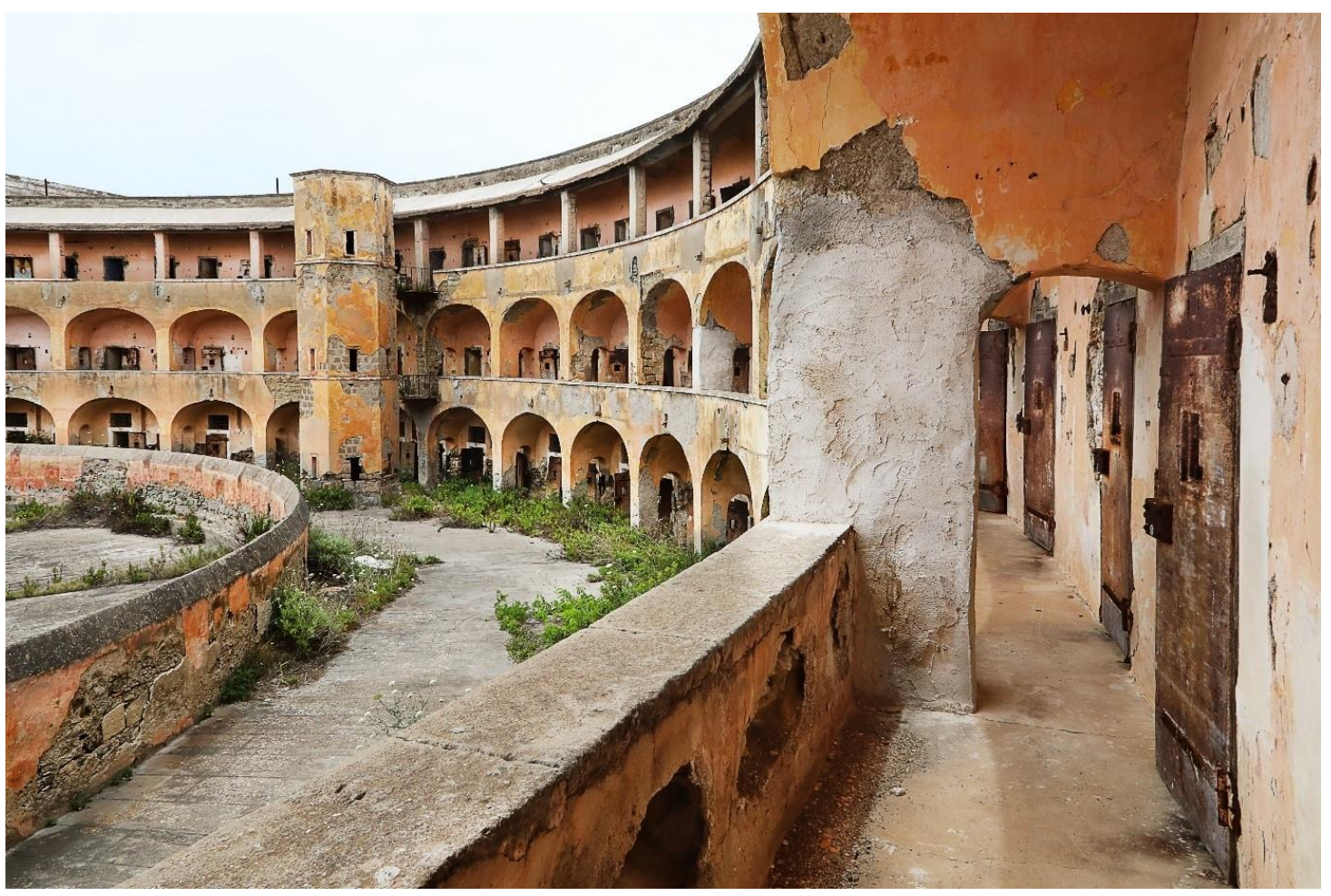

Figure 3. Island of Santo Stefano, view of the Panoptikon (photo credits Silvia Costa).

Flaminia Bartolini: What happened to the prison in the years after it was closed?

Silvia Costa: In 1965 the site of Santo Stefano started a new phase: in terms of both ownership and management and its intrinsic meaning. The first stage was in 1987 when the State recognized that the site had historical relevance and was therefore assigned to the Cultural Heritage national list by the Ministry of Culture.

The first handover in terms of management of the property took place in 1992, when the prison passed from being a State Property only to be the custody of the Municipality of Ventotene. From that date the Municipality of Ventotene had to take care of the ordinary and extraordinary maintenance, at a considerable cost and effort. At the end of the 1990s the enhancement and environmental protection of the area began, with the establishment of the Marine Protected Area and the State Nature Reserve. This is also the time when the two islands were linked together in terms of ownership and protection, emphasizing the inseparable link between the two islands.

The island was declared a National Monument by President Napolitano in 2008, to underline the importance of the site within the National Heritage, but it was only in 2016, with the restoration funding under the Renzi government, that the current project was financed. On that occasion President Renzi visited the island with German Chancellor 
Angela Merkel and French President François Hollande, to underline the historical importance of the place for European and not just Italian history.

Flaminia Bartolini: To conclude, what are your considerations regarding the future of the recovery processes of the prison?

Silvia Costa: The recovery and enhancement project of the Santo Stefano prison complex cannot ignore some fundamental and realistic considerations: the island of Santo Stefano is currently only accessible from two difficult access points; it has no water, electricity or sewage systems; as a nature reserve, a protected marine area and having archaeological sites, it has numerous restrictions. Finally, most of the island is privately owned.

It must also be said that these issues are also the reason why the island has been preserved intact and did not fall under predatory gentrification.

A further consideration is that the recovery of the prison must be an integrated project with the nearby island of Ventotene, not only as part of the same municipality but for a history that has always been intertwined between both the resident community and the prison.

If, on one side the fascist confinement was on Ventotene, the life imprisonment site of Santo Stefano shares the same traumatic memories, particularly for those politicians like Pertini and Terracini, who once in Santo Stefano were then transferred to Ventotene. If the idea of Europe was conceived on the island of Ventotene with its famous Carta, the history of both islands cannot be separated.

The project will therefore have to collect and reunify the documentation of both confinement and life imprisonment in order to educate people about detention, pain and redemption, deprivation of freedom, and the vision of the future from which democracy and development were born.

A third consideration is that there will be no possibility of reaching the end of this process even technically if the community of Ventotene and the surrounding territories, the Lazio Region, and all the institutional actors who sit on the Permanent Institutional Table (TIP) are not involved and signatories first of the Institutional Development Contract (CIS).

For this reason, since the beginning of my job, alongside the inspection activities and monitoring of the implementation of the commitments and interventions approved in the meetings of the Permanent Institutional Table, I wanted to work in two directions: through the strong involvement of the Municipality of Ventotene and also of local, national and European institutions, organizations, research and higher education bodies and associations in a broader Euro-Mediterranean horizon to elaborate and define the guidelines of the Feasibility Study for the overall Project. Collaboration between all the Administrations involved will allow shared solutions to be developed that will gradually be adopted in compliance with the existing constraints but also in the light of the common commitment.

I am pleased to be able to say that in fifteen months - despite the lockdown - we have approved the feasibility study of the project, entrusted the tender for the works for safety and conservation restoration of the Panopticon (currently in the start-up phase), completed the international design competition for the entire prison complex, and are at the final design phase for the landing point. 
Finally, the importance of defining a governance framework and management model with public/private partnerships is a challenge, particularly in light of recent legislative innovations which require sustainable development and new economic and employment opportunities. We have activated a program of involvement and active participation of the local community, of public and private partners who intend to support us in our commitment, as well as technological partners who can help us develop an all-inclusive project as a sign of quality, sustainability, and circular economy.

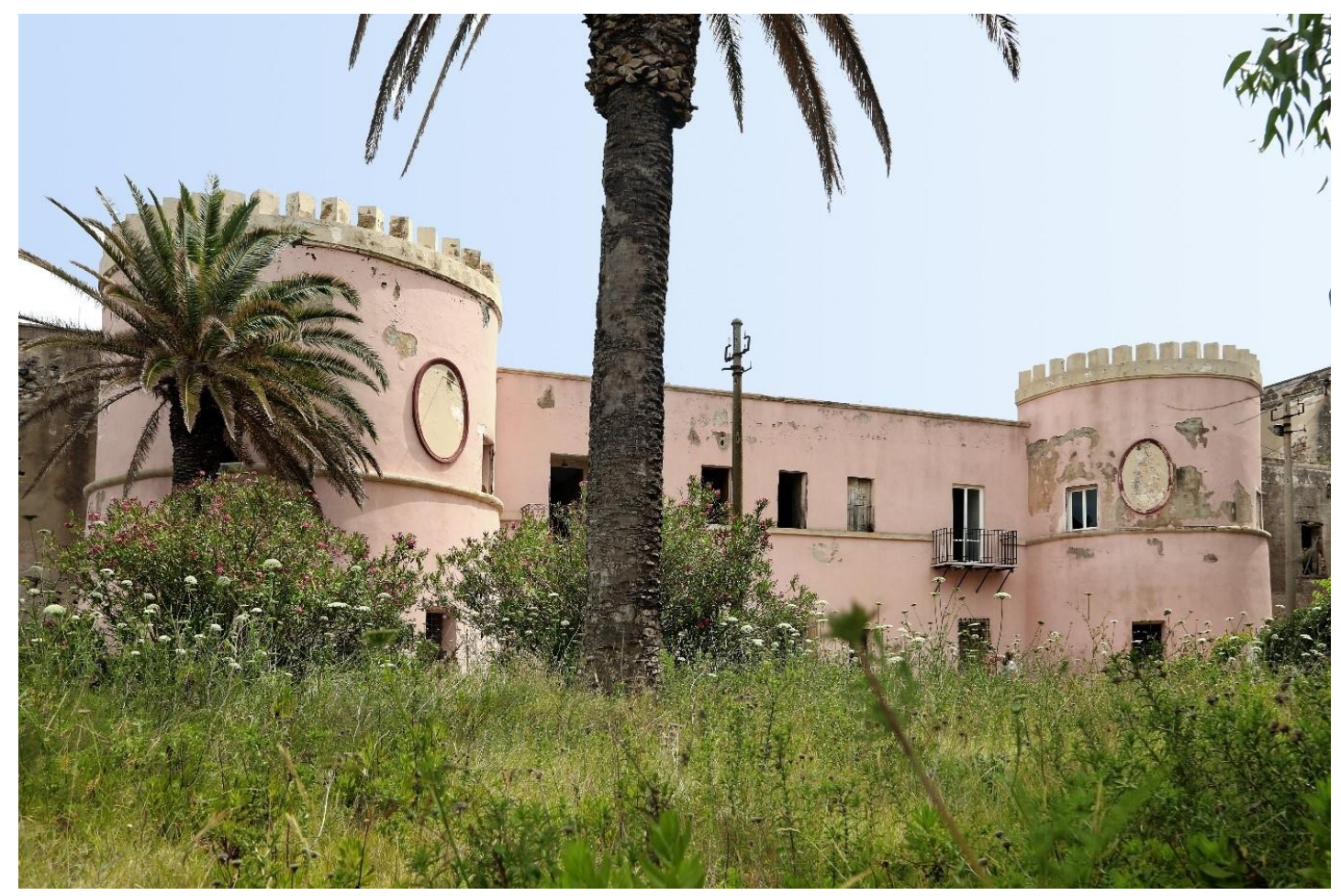

Figure 4. Island of Santo Stefano, prison complex main entrance (photo credits Silvia Costa).

\section{(Italian version)}

Flaminia Bartolini: Gentile Commissario, il ruolo affidatole dal Governo immagino sia per lei una sfida. Potrebbe parlarci del progetto?

Silvia Costa: Il progetto di recupero e rifunzionalizzazione dell'ex carcere borbonico sull'isola di Santo Stefano-Ventotene, chiuso e abbandonato da cinquant'anni, è una sfida culturale, etica e simbolica lanciata in Italia e in Europa dal Governo Renzi già nel 2016. Il Governo Conte, su impulso del Ministro Franceschini in cooperazione con il Ministro Provenzano, ha voluto rilanciare con forza e sostenere concretamente.

A tal fine il Governo mi ha affidato a fine gennaio, con il DPR47/2020, il ruolo di Commissario straordinario per assicurare il necessario coordinamento tra le Amministrazioni statali e per dare un significativo impulso anche operativo al progetto. Un compito affascinante e complesso di cui sento tutta la responsabilità per il grande valore di patrimonio culturale che questo luogo di "dolore, di espiaz̧ione e di redenzione" (per 
usare le parole dell'illuminato direttore Eugenio Perucatti) rappresenta nella storia e nella evoluzione in Italia e in Europa della cultura carceraria e penalistica e della tutela dei diritti umani e della dignità della persona.

Un fascino che proviene anche dall'impatto emotivo e dall'interesse che suscita nei visitatori il 'Panoptikon', una struttura peculiare nella edilizia carceraria in Europa, ispirato ad una concezione architettonica illuminista che conferisce a questo grande complesso monumentale un grande valore intrinseco.

Flaminia Bartolini: Gentile Commissario, potrebbe accennare alla storia del carcere di Santo Stefano?

Silvia Costa: L'isola di Santo Stefano e la vicina isola di Ventotene sono da sempre considerate isole di esilio coatto. Fu Giulia maggiore, figlia di Augusto, con la madre Scribonia, ad inaugurare la triste esperienza dell'esilio (I sec. a.C.), seguita da Agrippina maggiore per ordine di Tiberio, Ottavia, figlia di Claudio e moglie di Nerone e Flavia Domitilla, nipote di Domiziano.

Il progetto del carcere, e la sua realizzazione, sono dovuti al maggiore del Genio Antonio Winspeare, incaricato da Ferdinando I delle Due Sicilie di installare sull'isola un penitenziario che servisse a separare i detenuti dal resto della società. Winspeare si valse della collaborazione dell'architetto Francesco Carpi, il quale si rifece, per l'esecuzione del lavoro, ai principi illuministici propugnati dal filosofo inglese Jeremy Bentham. Tali principi, sviluppati dallo stesso Bentham nel suo piano di carcere ideale, denominato Panopticon, prevedevano che tutti i detenuti, rinchiusi nelle proprie celle disposte a semicerchio, potessero essere individualmente sorvegliati da un unico guardiano posto in un corpo centrale, senza sapere se fossero in quel momento osservati o meno. Tale disposizione architettonica era intimamente coerente con il principio benthamiano della dissuasione a fare il male derivante dalla consapevolezza di essere costantemente sotto controllo.

Anche dopo la caduta del Regno delle Due Sicilie, il carcere mantenne il proprio ruolo sotto il Regno d'Italia. In questo periodo, il carcere continuò ad accogliere detenuti comuni e speciali, tra cui il più noto capobrigante post-risorgimentale Carmine Crocco e l'anarchico Gaetano Bresci che uccise Re Umberto I di Savoia.

Durante il Ventennio fascista il carcere continuò ad essere un luogo privilegiato per la collocazione di dissidenti politici. Detenuti famosi di questo periodo furono Umberto Terracini, Mauro Scoccimarro, Rocco Pugliese e Sandro Pertini, più tardi diventato Presidente della Repubblica Italiana

Le cose cambiarono sostanzialmente quando, Eugenio Perucatti il nuovo direttore lì inviato nel 1952, fervente Cattolico e uomo determinato, volle dare uno scossone alla storia carceraria: un lento passaggio da una pena con finalità retributivo-deterrente ad una stagione di riflessione che dava il via, anche se le norme non lo prevedevano e le autorità erano sorde a questa nuova ventata di speranza, ad una stagione con finalità prevalentemente di risocializzazione e di recupero del soggetto alla società civile.

Attuò sotto la sua responsabilità nuovi sistemi penitenziari dove l'ozio diurno fu sostituito da attività lavorative, scolastiche e religiose. Dove il ricordo della famiglia e degli affetti furono sostituiti dalla possibilita' di avere visite dei familiari una volta l'anno. 
Un sogno che durò solo pochi anni: nel luglio del 1960 Perucatti veniva pomposamente trasferito ad incombenze amministrativo-ministeriali.

L'Ergastolo fu chiuso nel febbraio 1965, con Decreto del Ministero di Grazia e Giustizia.

Flaminia Bartolini: Cosa è successo al carcere negli anni dopo la chiusura?

Silvia Costa: I passaggi legislativi e di risignificazione che passano dalla chiusura del carcere nel 1965 all'attuale progetto di restauro e valorizzazione ruotano attorno al passaggio della proprietà del bene e alla sua definizione di Bene Culturale. Se infatti la chiusura della struttura penitenziaria è avvenuta da parte dal Ministero di Grazia e Giustizia, sarà l'iscrizione nel 1987 a "Bene di particolare interesse storico artistico" dal Ministero dei Beni Culturali e Ambientali a iniziare il suo processo di storicizzazione. Un primo passaggio di consegne in termini di possesso del bene avviene nel 1992, quando dal Demanio il carcere viene affidato al Comune di Ventotene per quanto concerne la custodia e valorizzazione, ovvero da quella data il Comune di Ventotene dovrà farsi carico della manutenzione ordinaria e straordinaria. Alla fine degli anni novanta inizierà la valorizzazione e a la tutela ambientale della zona, infatti risale a quel periodo l'istituzione dell'Area Marina Protetta e della Riserva Naturale Statale, entrambe con la nomenclatura Isole di Ventotene e Santo Stefano, a voler sottolineare il legame inscindibile tra le due isole.

L'isola verrà dichiarata Monumento nazionale dal Presidente Napolitano nel 2008, a voler sottolineare l'importanza del sito all'interno del patrimonio nazionale, per arrivare al 2016 con l'approvazione del finanziamento di restauro grazie alla Delibera CIPE sotto il governo Renzi. In occasione del finanziamento il Presidente Renzi portò in visita la Cancelliera tedesca Angela Merkel e il presidente francese François Hollande, a sottolineare l'importanza storica del luogo per la storia europea e non solo italiana.

Flaminia Bartolini: Quali sono per concludere le sue considerazioni per quanto riguarda la valorizzazione del carcere?

Silvia Costa: Questa importante opera di recupero e valorizzazione non può prescindere da alcune fondamentali e realistiche considerazioni: l'isola di Santo Stefano è attualmente accessibile solo da due approdi di difficile accessibilità, è priva di impianti idrici, elettrici e fognari e, in quanto Riserva naturale e Area marina protetta dalla fine degli anni novanta, nonché sede di significativi siti archeologici, ha numerosi vincoli e tutele, oltre ad essere per la maggior parte di proprietà privata. Nodi che vanno affrontati con determinazione ed equilibrio, anche se va riconosciuto che in tal modo è stata preservata da operazioni speculative e che, pur nel pericoloso degrado attuale, hanno preservato una forte identità del luogo.

La seconda considerazione è che deve essere un progetto integrato con la vicina isola di Ventotene, non solo come parte di uno stesso Comune ma per una storia che è sempre stata intrecciata tra la comunità residente e il carcere. Ed anche nel senso di avviare da subito la rete di partenariati che stiamo costruendo per realizzare nell'isola di Ventotene iniziative e attività che con lo sviluppo del Progetto saranno diversificate ed integrate con Santo Stefano. 
Se nella cittadella del confino di Ventotene, durante il fascismo, infatti, Altiero Spinelli, Eugenio Colorni e Ernesto Rossi hanno concepito e lanciato con il Manifesto per una Europa Libera e Unita, la prospettiva di una Europa federalista per la pace e la democrazia, nell'ergastolo di Santo Stefano lungo i duecento anni della sua storia sono sempre stati affiancati ai detenuti comuni numerosi oppositori politici fino ai costituenti Pertini e Terracini, poi trasferiti a Ventotene, che da lì trassero ispirazione e determinazione per scrivere i valori fondamentali della nostra Costituzione. Così come negli ultimi anni di funzionamento del carcere, tra il 1952 e il 1960, il rivoluzionario direttore Eugenio Perucatti, un giurista e dirigente penitenziario cattolico coraggioso e coerente, in nome dell'art.27 della Costituzione, ha rivoluzionato il carcere anticipando di venticinque anni la Riforma carceraria del 1975 e opponendosi allo stesso istituto dell'ergastolo, in sintonia con un altro giovane costituente, Aldo Moro. E ha pagato con un trasferimento punitivo questo suo impegno.

Il progetto dovrà dunque raccogliere e riunificare la documentazione e realizzare un archivio unitario del carcere raccontando alle nuove generazioni le sofferte esperienze di confino e detenzione, di dolore e riscatto, di privazione della libertà e visione del futuro da cui sono nate la democrazia, lo sviluppo e la pace in Italia e in Europa e che hanno ispirato i Padri fondatori.

Infine, una terza considerazione. Non ci sarà la possibilità di giungere alla fine di questo percorso così complesso anche tecnicamente se non sarà coinvolta e partecipe innanzitutto la comunità di Ventotene, la Regione Lazio e tutti gli attori istituzionali e non che sono più prossimi geograficamente o idealmente.

Per questo, fin dall'inizio del mio mandato, accanto alle attività di sopralluogo e di impulso e monitoraggio dell'attuazione degli impegni approvati nella riunione del Tavolo Istituzionale Permanente del 4 giugno 2020, ho voluto lavorare in due direzioni: il forte coinvolgimento del Comune di Ventotene e di Istituzioni, organismi, Enti di ricerca e di alta formazione ed Associazioni locali, nazionali ed europee anche in un più ampio orizzonte euromediterraneo per elaborare e definire le linee guida dello Studio di Fattibilità del Progetto complessivo In grande collaborazione tra tutte le Amministrazioni coinvolte favorendo la condivisione delle soluzioni che via via saranno adottate nel rispetto dei vincoli esistenti ma anche alla luce del comune impegno, solennemente assunto nel Contratto Istituzionale di Sviluppo, di concorrere alla tutela del bene e della sua fruizione. Non mi sfugge infine l'importanza di definire un quadro di governance e di modelli di gestione con partenariati pubblici e privati, anche alla luce delle recenti innovazioni legislative, che possano ingenerare sviluppo sostenibile e nuove opportunità economiche e occupazionali. Ma abbiamo anche attivato, come dimostra l'iniziativa corale del 17 settembre 2021, un metodo di coinvolgimento e partecipazione attiva della comunità locale, di partners pubblici e privati che intendono affiancarci nel nostro impegno, nonché di partners tecnologici che ci aiutino a sviluppare un progetto all'insegna della qualità, sostenibilità ed economia circolare. 


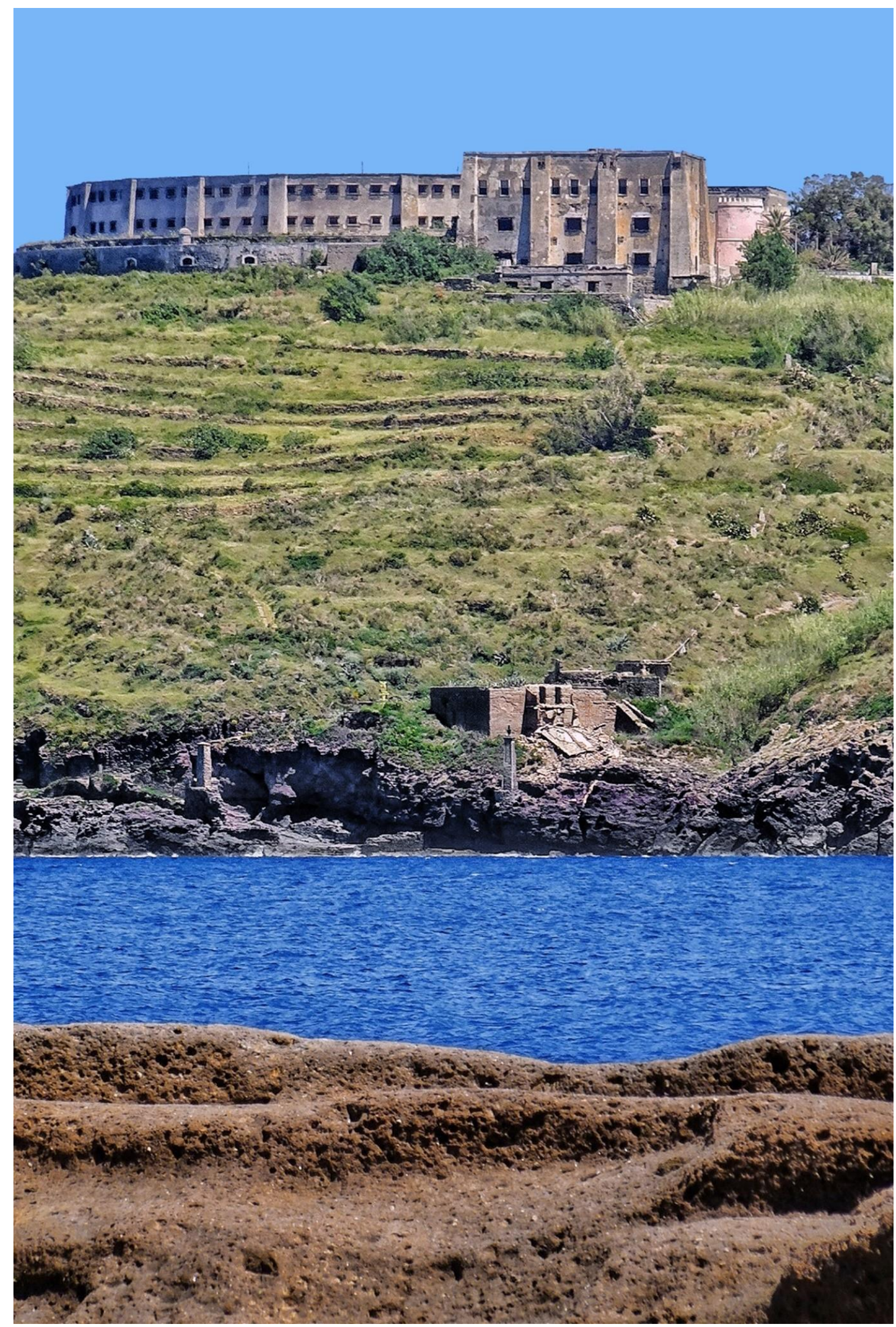

